\title{
Analysis Of Sport Practise In Young Teen Immigrants In The Town Of Cuenca
}

\author{
Andrés Valencia-García, University of Castilla-La Mancha, Spain \\ José Mondéjar-Jiménez, University of Castilla-La Mancha, Spain \\ Isabel-María Ferándiz-Vindel, University of Castilla-La Mancha, Spain \\ Eugenio-Enrique Córtes-Ramírez, University of Castilla-La Mancha, Spain \\ Maria-del-Val Segarra-Oña, Universitat Politècnica de València, Spain
}

\begin{abstract}
Adolescence is a critical period for the acquisition of healthy habits. Every day there is more evidence that lifestyle has a deeply influence on the health of individuals. For this reason, the adoption of healthy habits or changing bad habits will provide beneficial effects on both health and people's quality of life.

Sport practice in adolescents is being analyzed through this paper. Our empirical work has been focused on teen immigrant population who currently lives in the town of Cuenca (Spain). Therefore, a survey has been conducted among this kind of population in order to obtain a complete profile of them and to make a comparison with the teen native population in Cuenca in forthcoming research.
\end{abstract}

Keywords: Immigrant Youth; Sport; Cuenca (Castilla - La Mancha, Spain)

\section{INTRODUCTION}

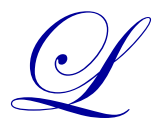

ifestyle in adolescents has been the subject of numerous studies, which often differ in the factors that determine it. There is consensus, moreover, when physical activity, exercise and sport as some of these factors are included (Jiménez, 2004; Mendoza, Sagrera \& Batista, 1994; Pastor, Balaguer \& García, 1998; Rodrigo, Máiquez-García, Mendoza, Rubio, Martínez \& Martín, 2004).

In this paper we are focusing on sport. Nowadays an accepted definition is that of Hernández $(1994$, p. 15) which defines it as a "driving situation of competition that has been ruled under a ludic and institutionalized character." According to this, sport has been characterized and provided with a number of features such as: its "ludic nature"; the implementation of a "physical activity", more or less complex, for those who practice it; the existence of "competition" either as a brand or as an opponent; the respect for those "rules" that are known and accepted by everybody and the "institutionalization" or control by means of governmental institutions.

There are countless studies that have attempted to describe and to analyze the sport of young teenagers from a healthy environment. However, there are also less common reports, those which are focused on a specific group of people such as the young immigrants, despite their spectacular rate increase that we have seen in Spain, from 637,085 in 1998 to 5,751,487 in 2011.

The town of Cuenca has not remained untouched by this true demographic implosion. In fact, Cuenca has been transformed by this young immigration in an educational, economic, social and cultural way. The latest data from the local census raises the percentage of immigrant population at $10.1 \%$, of which a $9.7 \%$ comes from the nonEU countries and a 0.4\% from the European Union. During the Academic Year 2010-2011, there were a whole of 266 immigrant students who were registered in the town of Cuenca, those who were representing a $12.02 \%$ of the total student body. 


\section{MATERIALS AND METHODS}

The population of immigrant students who is registered in the Compulsory Secondary Education System (ESO) at the secondary schools in the town of Cuenca is represented by the selected sample. From a total number of 266 registered immigrant students, we have only analyzed a whole of 173 . Regarding the total parameters, we have obtained error levels below 5\% (4.4\%) for a level of trust of 95\%. The reason for these low levels of error is the censual nature of this study.

The students who are analyzed in the sample are comprised in an age range between 13 and 18 years, being an average age of 14.89 years $(\mathrm{SD}=1,187) .52 \%$ of these students are male $(\mathrm{N}=90)$ and $48 \%$ are female $(\mathrm{N}=83)$. $30.6 \%$ of these students are studying their $1^{\text {st }}$ year of ESO and their average age is $13.77(\mathrm{DT}=0.577) .41 \%$ of these students are currently studying $2^{\text {nd }}$ year of ESO and their average age is 14.89 (DT $\left.=0.854\right) .19 \%$ of these students are currently studying $3^{\text {rd }}$ year of ESO and their average age is $15.88(\mathrm{DT}=0.793)$. At last, $9.2 \%$ of these students are currently studying $4^{\text {th }}$ year of ESO and their average age is $16.63(\mathrm{DT}=0.719)$.

The instrument that has been employed in our study is an adaption from the HBCS translation (Wold, $1995)$ into Spanish which was implemented by Balaguer $(1999,2002)$. In Spain this instrument has also been used in numerous studies (Castillo \& Balaguer, 2001; Jiménez, 2004; Moreno, 2004; Miller, Castro Ruiz, Gonzalez Marquez \& Mora, 2010).

An exclusively quantitative analysis has been carried out through those relevant data that had been obtained from the sport studied variable. SPSS (Statistical Product and Service Solutions, 19.0 version) was the software that has been used. Data statistic treatment has been implemented by means of data descriptive treatment, being frequency the main one.

\section{RESULTS} these being:

The main results that have been obtained from the survey derived information derived from the survey,

\section{a) Quantitative Aspects of Sport Practice}

On the one hand, the study shows that the highest percentage is taken between those students who practiced sport twice or three times a week (38.6\%), reaching until 69.3\% those who practiced sports once a week at least. On the other, there are a high percentage of students who regularly or never did do sports $(30.7 \%)$.

Generally speaking, sport practice intensity follows the same line of physical activity, being focused on the highest percentages from those students whose performance is varying from moderate to heavy intensities $(73.4 \%)$ over those who do so very strong $(15.6 \%)$ or mild $(11.1 \%)$. As expected, sport practice lasting is superior to physical activity. $65.2 \%$ has been carried out for longer than forty-five minutes. This could have happened thanks to sport regulated nature, which differs from physical activity practice. Frequency, intensity and sport lasting descriptive treatments are summarized by this following table (Valencia, 2013).

Table 1: Sport Practice Descriptive Treatment: Frequency, Intensity and Duration (Spanish)

\begin{tabular}{|l|c|c|c|c|c|}
\hline \multicolumn{1}{|c|}{ Frecuencia } & $\mathbf{\%}$ & Intensidad & $\mathbf{\%}$ & Duración & $\%$ \\
\hline Nunca & 21,7 & Muy intenso & 15,6 & Más de cuarenta y cinco minutos & 65,2 \\
Menos de una vez por semana & 9 & Intenso & 34,1 & Treinta y cinco minutos & 13,3 \\
Una vez por semana & 16,3 & Moderado & 39,3 & Veinticinco minutos & 9,6 \\
Dos- tres veces por semana & 38,6 & Ligero & 11,1 & Quince- veinticinco minutos & 4,4 \\
Cuatro-cinco veces por semana & 10,8 & & & Cinco- quince minutos & 4,4 \\
Seis- siete veces por semana & 3,6 & & Menos de cinco minutos & 3 \\
\hline Total & 100 & Total & 100 & Total & 100 \\
\hline
\end{tabular}




\section{b) Sport Practice Institutionalization Degree}

The results show a large majority of students who practiced sports far away from sports clubs (73.3\%) and school teams $(89.5 \%)$. Regarding the form of practice, $15.4 \%$ of students practiced sport alone.

Table 2: Sport Practice Institutionalization (Spanish)

\begin{tabular}{|c|c|c|c|c|c|c|c|}
\hline Miembro de club & $\%$ & $\begin{array}{c}\text { Miembro equipo } \\
\text { escolar }\end{array}$ & $\%$ & $\begin{array}{c}\text { Participación en } \\
\text { competiciones }\end{array}$ & $\%$ & Forma de práctica & $\%$ \\
\hline $\begin{array}{c}\text { No } \\
\text { Sí, estoy entrenando } \\
\text { en un equipo de } \\
\text { deportes } \\
\text { Sí, pero no participo }\end{array}$ & $\begin{array}{c}24,4 \\
2,3\end{array}$ & $\begin{array}{c}\text { No } \\
\text { Sí, estoy entrenando } \\
\text { en un equipo de } \\
\text { deportes } \\
\text { Sí, pero no participo }\end{array}$ & $\begin{array}{l}9,3 \\
1,2\end{array}$ & $\begin{array}{c}\text { Si } \\
\text { No } \\
\begin{array}{c}\text { Lo hacía, pero ya no lo } \\
\text { hago }\end{array}\end{array}$ & $\begin{array}{l}39,5 \\
37,8 \\
22,7\end{array}$ & $\begin{array}{c}\text { Solo } \\
\text { Con otros } \\
\text { A veces solo y a } \\
\text { veces con otros }\end{array}$ & $\begin{array}{l}15,4 \\
46,2 \\
38,5\end{array}$ \\
\hline Total & 100 & Total & 100 & Total & 100 & Total & 100 \\
\hline
\end{tabular}

\section{c) Sports Practice in the Closest Environment}

The results of this study show a higher frequency in motivating practice by parents, being mother's motivation "very often" higher (38\%) than father's (36.6\%).

After the parents, students' best friend (31.7\%) is who provides a lot of mood for sport practice, very superior to the older brother (15.8\%) and to the sister (7.7\%), who seems to encourage less. However, it should be pointed out that these results are referred to quantitative aspects, or encouragement amount, without valuing either perception or environment implications on the subject's behavior (Valencia, 2013).

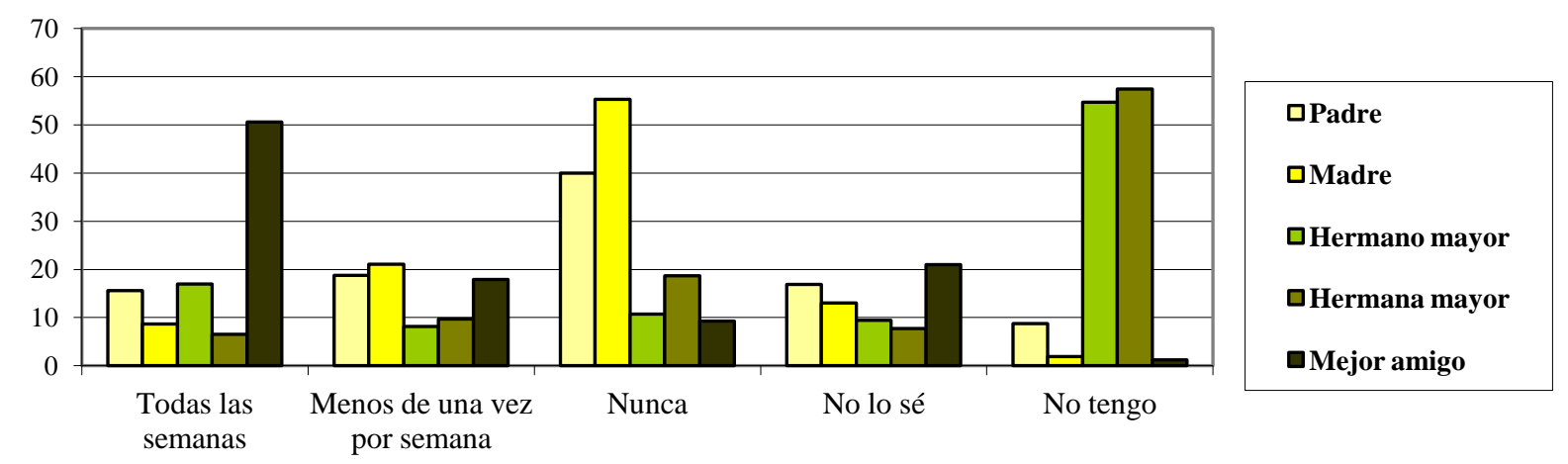

Figure 1: Closest Sports Environment (Spanish)

\section{d) Sport Practice Motivation of the Closest Environment}

The results of this study show a higher frequency in motivating practice by parents, being mother's motivation "very often" higher (38\%) than father's (36.6\%).

After the parents, students' best friend (31.7\%) is who provides a lot of mood for sport practice, very superior to the older brother (15.8\%) and to the sister (7.7\%), who seems to encourage less (Valencia, 2013). 


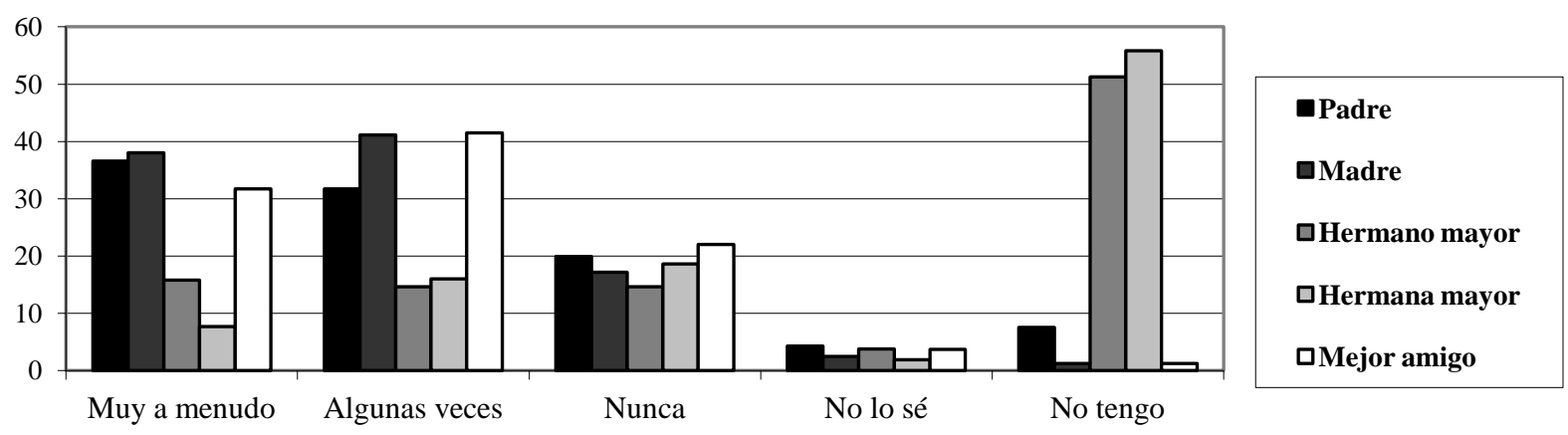

Figure 2: Sport Practice Motivation of the Closest Environment (Spanish)

\section{e) Reasons for Sport Practice}

According to the study results, the most frequent reasons for the fun sport are fun (78.2\%), health improvement $(76.4 \%)$ and fitness $(68.9 \%)$, as the following figure reveals, this being:

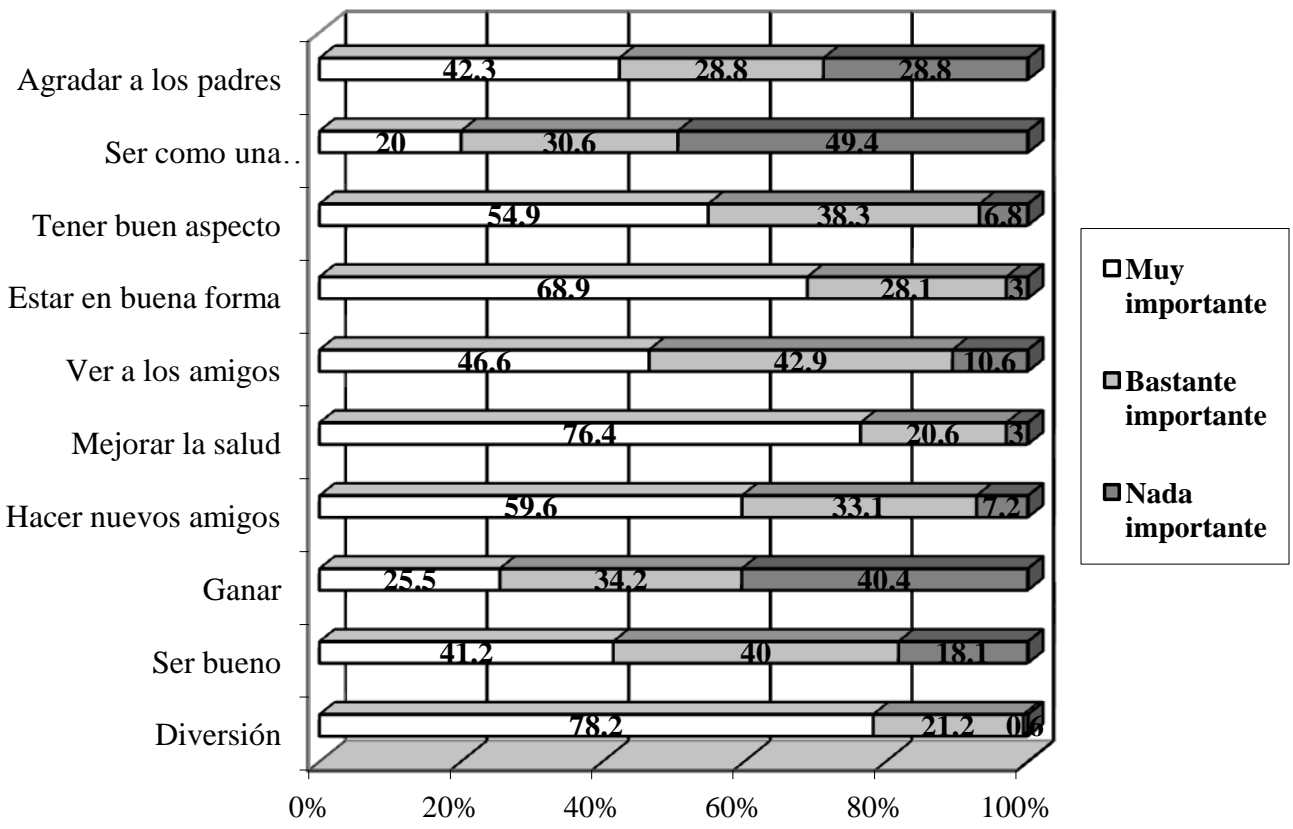

Figure 3: Reasons for Sport Practice (Spanish)

\section{CONCLUSIONS}

In this mainly descriptive study, we have conducted an observation of one of the variables that has had a deeply influence on the lifestyle of adolescents, this being sports practice. Regarding young immigrants, we could conclude that:

- $\quad$ Sport practice is a little studied phenomenon to which we must pay more attention, considering the high percentage of the total population that they are representing.

- Spain is said to be one of the least active countries in sport practice in our political environment. This situation is not different from the study population. As far as sport practice is concerned, there are a high percentage of students who never have practiced or made it less than once a week $(30.7 \%)$. However, the practice profile is 2-3 times a week at moderate intensity and lasting no longer than 45 minutes. 
Immigrant students practice sport in a so little institutionalized way, far away from sports clubs and school teams. However, this kind of students practice sport in the company of others and those who practice sport alone are reduced to $15.4 \%$. Their circle of friends is who practice sports the best, but it is their parents who encourage their practice the best. Finally, fun and health improvement are the main reasons for sport practice in young teen immigrants.

Physical Education at schools, as a channel for sports habits, should affect all these aspects, fostering a fun environment, awareness of the sport importance effect on their health. In addition, these immigrant students must build structures to enable their practice and integrate their most immediate environment, regarding the common integration problems common to many young immigrants.

In this last sense, it seems necessary to integrate actions in the Center Education Project and to seek the participation of the different colleges or school bodies, which make up school life, such as counseling teams, through the Tutorial Action Plan, Students Parents Associations, Faculty, etc.

\section{AUTHOR INFORMATION}

Andrés Valencia-García holds a PhD in Education from the University of Castilla-La Mancha and is a Physical Education Teacher in Cuenca (Spain). Dr. Valencia-Garcia's research interests include educational, physical education and immigrations. Phone +34 902204 100; Fax +34 902204 130. E-mail: andresvagar@ hotmail.com

José Mondéjar-Jiménez holds a European $\mathrm{PhD}$ in Economics and Degree in Business Administration from the University of Castilla-La Mancha and is an Associate Professor in Statistics at the University of Castilla-La Mancha, Statistics Department. Faculty of Social Sciences of Cuenca, Spain. Dr. Mondejar-Jimenez's research interests include regional analysis, educational and tourism. Phone +34 902204 100; Fax +34 902204 130. E-mail: Jose.Mondejar@uclm.es (Corresponding author)

Isabel $\mathbf{M}^{\mathbf{a}}$ Ferrándiz Vindel holds a PhD and Degree in Education Sciences from the Complutense University of Madrid (UCM), Spain and is a professor in the Pedagogy Department, Faculty of Education Sciences and Humanities of Cuenca, University of Castilla-La Mancha (Spain). Dr. Ferrandiz Vindel's research interest includes inclusive education of disabled people. E-mail: Isabel.Ferrandiz@uclm.es

Eugenio-Enrique Cortés-Ramírez holds a PhD in Philosophy from the Autonoma University of Madrid, Spain and a PhD in Political Science from IEP of Paris. Dr. Cortes-Ramirez is an Assistant Professor at the Department of Modern Languages, University of Castilla - La Mancha, Spain. Dr. Cortes-Ramirez's research interests include British philosophy, comparative cultural studies and English language for specific \& professional purposes. Phone: +34 969179 100. E-mail: EugenioE.Cortes@uclm.es

María-del-Val Segarra-Oña holds a PhD in Management and Degree in Industrial Engineering and is an Associate Professor in Innovation and Competitiveness at the School of Industrial Engineering, Universidad Politécnica, Valencia (Spain). Dr. Segarra-Ona's research interests include environmental proactivity and eco-innovation. E-mail: maseo@omp.upv.es

\section{REFERENCES}

1. Balaguer, I., \& Castillo, I. (2002). Actividad física, ejercicio físico y deporte en la adolescencia. En I. Balaguer (Ed.), Estilos de vida en la adolescencia (pp. 37-64). Valencia: Promolibro.

2. Castillo, I., \& Balaguer, I. (2001). Dimensiones de los motivos de práctica deportiva de los adolescentes valencianos escolarizados. Apunts de Educación Física y Deportes, 63, 22-29.

3. Hernández, J. (1994). Fundamentos del deporte. Análisis de las estructuras del juego deportivo. Barcelona: INDE.

4. Jiménez, R. (2004). Motivación, trato de igualdad, comportamientos de disciplina y estilos de vida saludables en estudiantes de Educación Física en secundaria. Tesis doctoral. Facultad de Ciencias del Deporte. Universidad de Extremadura. 
5. Mendoza, R., Sagrera, M. R., \& Batista, J. M. (1994). Conductas de los escolares españoles relacionados con la salud (1986-1990). Madrid: Consejo Superior de Investigaciones Científicas.

6. Moreno (2004). Un estudio de la influencia del autoconcepto multidimensional sobre el estilo de vida saludable en la adolescencia temprana. Tesis doctoral. Facultad de Psicología. Valencia: Servicio de publicaciones de la Universidad de Valencia.

7. Molinero, O., Castro, J., Ruiz, J. R., González, J. L., Mora, J., \& Márquez, S. (2010). Conductas de salud en escolares de la provincia de Cádiz. Nutrición Hospitalaria, 25(2), 280-289.

8. Pastor, Y., Balaguer, I., \& García, M. L. (1998). Una revisión sobre las variables de estilos de vida saludables. Revista de Psicología de la Salud, 10(1), 15-52.

9. Rodrigo, M. J., Máiquez, M. L., García, M., Mendoza, R., Rubio, A., Martínez, A., \& Martín, J. C. (2004). Relaciones padres-hijos y estilos de vida en la adolescencia. Psicothema, 16(2), 203-210.

10. Valencia, A. (2013). Hábitos saludables de los jóvenes adolescentes inmigrantes en la ciudad de Cuenca. Tesis doctoral. Universidad de Castilla-La Mancha. 